\title{
IMPLEMENTATION OF THE SIAGA VILLAGE PROGRAM FOR COVID-19 PREVENTION IN BALI, INDONESIA
}

\author{
Ni Kadek Widyanti ${ }^{1}$, I Ketut Widnyana ${ }^{\square}$ (D) I Putu Sujana ${ }^{1}$ and Ni Putu Pandawani ${ }^{1}$ \\ ${ }^{1}$ Magister in Regional Planning and Environmental Management, Postgraduate Program at University Mahasaraswati of \\ Denpasar Indonesia
}

Received 26 March 2021

Accepted 12 April 2021

Published 30 April 2021

Corresponding Author

I Ketut Widnyana, widnyanaketut

@gmail.com

DOI $10.29121 /$

granthaalayah.v9.i4.2021.3841

Funding: This research received no specific grant from any funding agency in the public, commercial, or not-for-profit sectors.

Copyright: (C) 2021 The Author(s). This is an open access article distributed under the terms of the Creative Commons Attribution License, which permits unrestricted use, distribution, and reproduction in any medium, provided the original author and source are credited.

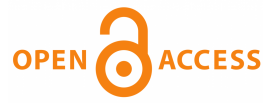

\section{ABSTRACT}

Abuan Village, Susut District, Bangli Regency is one of the Siaga Villages in Bali. Siaga Village is a picture of a community that is aware, willing, and able to prevent and overcome various threats to public health. However, in Abuan Village, there had been a case where the community was confirmed positive for significant Covid-19. This condition raises the question of why the covid-19 incident can occur in Siaga Village. The purpose of the research is to know the implementation of Siaga Village program in Prevention Covid 19 in the Abuan village of Bangli regency. This research uses qualitative and quantitative approaches through SWOT analysis and followed by IFAS and EFAS matrices, with 30 respondents taken purposively. The results showed that the implementation of the Siaga Village program for the prevention of the Corona Covid-19 virus disease in Abuan Village Bangli Regency was generally in a very good category. The factors that determine the implementation of the Siaga village program in efforts to prevent Covid-19 consist of internal factors, namely clean and healthy living habits at the household level, access to health services, and village forums. The external factor is the existence of negative information (hoax) from social media about Covid-19 and other health. The strategy for implementing the Siaga village program is to carry out clean and healthy household behavior, carry out village forums regularly, update Decree Letters, disseminate correct information about the Covid-19 virus disease, and increase the role of health cadres.

Keywords: Siaga Village, Covid19 Prevention, Implementation

\section{INTRODUCTION}

Siaga Village is a picture of a community that is aware, willing, and able to prevent and overcome various threats to public health such as malnutrition, infectious diseases, disasters, accidents, and others. The Guidelines for Implementing Siaga Village Development are regulated in the Decree of the Minister of Health of the Repub- 
lic of Indonesia No. 564/Menkes/ SK/VIII/2006 (Kesehatan and I (2010) ). The core of Siaga Village activities is to empower the community so that they are willing and able to live healthily. Therefore, in developing a Siaga village, an educational approach is needed, namely an effort to assist (facilitate) the community to undergo a learning process in the form of a process of solving health problems it faces through Community-Based Health (UKBM) efforts as an embryo or the starting point of development towards Siaga Village. The key to the success and sustainability of Siaga Village is the activeness of health cadres. To realize the Siaga Village program, the role of the midwife is not limited to handling maternal and child health problems, but also must be able to mobilize and empower rural communities to be directly involved in health problems, such as the current situation when the community is faced with the Covid-19 pandemic situation.

Coronavirus Disease-19 (COVID-19) is an infectious disease caused by the SARSCOV 2 virus or Corona Virus. In early 2020 the government declared Covid-19 a non-natural disaster in the form of a disease outbreak with an increasing number of cases in various regions in Indonesia, this incident forced the central and local governments to take steps to prevent the spread and control of the disease by limiting community activities which involves many people such as teaching and learning activities, working in offices, entertainment activities and even closing routes and modes of public transportation. This has a huge impact on the state's financial condition in particular, as well as the economy of the people in general. The government needs the cooperation and awareness of all levels of society in efforts to handle and prevent the spread of COVID-19. The Siaga Village Program is very appropriate to be developed in the face of a disaster situation such as the current pandemic. To develop this program, a strategy that is adapted to existing local resources is needed. The purpose of this research was to determine the implementation of the Siaga Village Program to prevent Covid-19 in Abuan Village, Susut District, Bangli Regency.

\section{MATERIALS AND METHODS}

This type of research is observational, with a research design using a combination of qualitative and quantitative methods. This research was conducted in Abuan Village, Susut District, Bangli Regency. The location of the study was carried out by purposive sampling, with the criteria that the "Siaga village" program had been active for at least 5 years, and there had been an increase in cases of the Covid-19 pandemic. The time of research is in October-December 2020. The research subjects were taken as many as 30 people by purposive sampling. The instrument used was in the form of a questionnaire. The variables measured to refer to the theory of George Chares Edward III (1980) which consists of 4 (four) variables in the implementation of public policies, namely communication variables, resource variables, attitude and commitment variables from program implementers, and bureaucratic structure variables. Data collection techniques and procedures were carried out by survey and interview techniques, 
document review, field observations, and Focus Group Discussions (FGD). Data were analyzed using SWOT analysis and continued by using the IFAS and EFAS matrices (Misnaniarti (2011)).

\section{RESULTS AND DISCUSSION}

\subsection{IMPLEMENTATION OF THE SIAGA VILLAGE PROGRAM}

The evaluation of the implementation of the Siaga Village program was carried out by filling out a questionnaire given to 30 respondents. It was found that the implementation of the Siaga Village program in Abuan Village, Susut District, Bangli Regency was in a very good category (Table 1 ). The implementation of policies or programs is a crucial stage in the public policy process. A policy or program must be implemented to have the desired impact or purpose. Policy implementation is seen in a broad sense as a means of public administration in which actors, organizations, procedures, techniques, and resources are organized together to carry out policies to achieve the desired impact or goal.

Table 1 Implementation of theSiaga Village Program in Abuan Village, Bangli Regency

\begin{tabular}{|cccccc}
\hline No. & Variable Assessed & Score Obtained & Highest Score & Score (\%) & Category \\
\hline 1 & Communication & 145 & 150 & 96.67 & Very good \\
\hline 3 & $\begin{array}{c}\text { Availability of } \\
\text { resources }\end{array}$ & 267 & 300 & 89.00 & Very good \\
\hline & $\begin{array}{c}\text { Attitude and } \\
\text { commitment from } \\
\text { program } \\
\text { implementers }\end{array}$ & 166 & 180 & 92.22 & Very good \\
\hline Bureaucratic & 19 & 30 & 63.33 & Good \\
\hline & Structure & & & & Very good \\
\hline
\end{tabular}

Note: The score obtained / the highest score x $100 \%$

The data in Table 1, indicate that that program Siaga village has been running as a maximum, because of all the variables studied, both of variable communication, availability of resources, the attitude and commitment of the program managers, and bureaucratic structures are all in the category of good to very good. This is following the annual report of the Puskesmas Susut II in 2019, that Abuan Village in Bangli Regency is an active Siaga village for the Pratama stage, of the 8 phasing criteria, only the criteria for the Siaga village forum have made this program unable to reach a higher stage. In 2019 there was Siaga village forum characterized by the Decree of the forum, but the forum does not run on a regular well each quarterly or monthly, as evidenced by the absence of documents showing the list of attendees, meeting minutes, as well as photo documentation of activities. Another criterion that can affect the consistency of the Siaga Village program is the commitment of the policyholders and the community itself. Several studies have been conducted to determine the con- 
dition of the Siaga Village program. Misnaniarti (Misnaniarti (2011) ) in his research found that the Siaga village in Ogan Ilir Regency was still based on a top-down and the formation of a Siaga village had not fully utilized the potential of various existing community-based activities. Maharani, et al. (Maharani et al. (2018) ) also stated that the implementation of the Siaga village program in Semarang Regency had experienced a hiatus for several years, then the Siaga village was re-established with a Siaga village organizational structure, and implementing midwife for a Siaga village, a village ambulance facility, and Siaga village training for cadres.

\subsection{IDENTIFICATION OF INTERNAL AND EXTERNAL FACTORS}

Table 2 Internal Matrix for the Implementation of the Siaga VillageProgram in the Efforts to Prevent Covid-19 in Abuan Village, Bangli Regency

\begin{tabular}{|c|c|c|c|}
\hline Internal factors & Weight & Rating & $\begin{array}{l}\text { Score } \\
\text { (Weight x } \\
\text { Rating) }\end{array}$ \\
\hline \multicolumn{4}{|l|}{ Strength } \\
\hline 1.Socialization of the Siaga Village program & 0.07 & 3.60 & 0.26 \\
\hline $\begin{array}{l}\text { 2.Household clean and healthy living behavior } \\
\text { Guidance }\end{array}$ & 0.08 & 4.00 & 0.31 \\
\hline $\begin{array}{l}\text { 3.There are more than } 9 \text { health cadres in the vil- } \\
\text { lage }\end{array}$ & 0.07 & 3.80 & 0.28 \\
\hline 4.Training for cadres has been conducted & 0.07 & 3.60 & 0.26 \\
\hline 5.Access to affordable health services & 0.08 & 4.00 & 0.31 \\
\hline $\begin{array}{l}\text { 6.Posyandu and other active Community-Based } \\
\text { Health }\end{array}$ & 0.07 & 3.80 & 0.28 \\
\hline 7.There is information media about Covid-19 & 0.08 & 3.90 & 0.30 \\
\hline $\begin{array}{l}\text { 8.Community participation and community orga- } \\
\text { nizations }\end{array}$ & 0.08 & 3.90 & 0.30 \\
\hline 9.Financial support from the government & 0.08 & 3.90 & 0.30 \\
\hline $\begin{array}{l}\text { 10.There is a health regulation issued by the vil- } \\
\text { lage }\end{array}$ & 0.07 & 3.60 & 0.26 \\
\hline \multicolumn{4}{|l|}{ Weakness } \\
\hline $\begin{array}{l}\text { 1.Coaching, monitoring and evaluation of the Siaga } \\
\text { Village Program }\end{array}$ & 0.03 & 1.30 & 0.03 \\
\hline $\begin{array}{l}\text { 2.Village forums are not routinely held every } \\
\text { month }\end{array}$ & 0.05 & 2.50 & 0.12 \\
\hline 3.The guidebook related to the Siaga village & 0.04 & 2.20 & 0.10 \\
\hline $\begin{array}{l}\text { 4. Recording and reporting of Siaga village activi- } \\
\text { ties have not been organized, including during the } \\
\text { Covid- } 19 \text { pandemic }\end{array}$ & 0.05 & 2.40 & 0.11 \\
\hline $\begin{array}{l}\text { 5.The decree Forum is not regularly updated every } \\
\text { year }\end{array}$ & 0.05 & 2.50 & 0.12 \\
\hline $\begin{array}{l}\text { 6.The active role of cadres during the Covid-19 } \\
\text { pandemic }\end{array}$ & 0.04 & 1.80 & 0.06 \\
\hline IFAS TOTAL SCORE & 1.00 & & 3.41 \\
\hline
\end{tabular}


Determination of internal and external factors based on the results of field observations, document review, questionnaire distribution, and Focus Group Discussion (FGD). Internal factors consist of Strengths and Weaknesses, while external factors consist of Opportunities and Threats. These factors are presented in Table 2 and Table 3 .

The results of the calculation of the internal factor value obtained the total value (strengths and weaknesses) is 3.41. The matrix above shows the components in the strength factor have a balanced weight, namely 0.08 for 5 components and 0.07 for 5 components as well, while the rating value varies. The results of the score (multiplication of weight with rating) obtained the highest strength value found in 2 components with a value of 0.31 , namely about the development of clean and healthy living behavior, and access to health services. Weakness factors have varying weights with the highest score being 0.12 , namely regarding the involvement of community leaders in village forums on health and components of the Decree Forum which have not been updated regularly every year.

Table 3 ExternalMatrix for the Implementation of the Siaga Village Program in theEfforts to Prevent Covid-19 in Abuan Village, Bangli Regency

\begin{tabular}{|c|c|c|c|}
\hline Tors of factors external & Weight & Rating & $\begin{array}{l}\text { Score } \\
\text { (Weight x Rat- } \\
\text { ing) }\end{array}$ \\
\hline \multicolumn{4}{|l|}{ Opportunity } \\
\hline 1.Support from the village & 0.09 & 3.90 & 0.36 \\
\hline $\begin{array}{l}\text { 2.There is commitment from village officials } \\
\text { and the community }\end{array}$ & 0.09 & 3.90 & 0.36 \\
\hline 3.Budget allocation policy & 0.07 & 3.00 & 0.21 \\
\hline 4.Access to health services & 0.09 & 3.70 & 0.32 \\
\hline 5.Regional strategic plan indicators & 0.09 & 3.70 & 0.32 \\
\hline $\begin{array}{l}\text { 6.Other Community-Based Health Posyandu are } \\
\text { active }\end{array}$ & 0.09 & 3.80 & 0.34 \\
\hline $\begin{array}{l}\text { 7.There is the participation of the community } \\
\text { and community organizations }\end{array}$ & 0.09 & 3.90 & 0.36 \\
\hline $\begin{array}{l}\text { 8.Dissemination of information about Covid-19 } \\
\text { through various media }\end{array}$ & 0.09 & 3.70 & 0.32 \\
\hline $\begin{array}{l}\text { 9.Financial support from the business world } \\
\text { (CSR) }\end{array}$ & 0.09 & 3.70 & 0.32 \\
\hline \multicolumn{4}{|l|}{ Threat } \\
\hline $\begin{array}{l}\text { 1.During the Covid-19 pandemic, people } \\
\text { returned to their hometowns }\end{array}$ & 0.03 & 1.40 & 0.05 \\
\hline 2.Number of cadres & 0.05 & 2.10 & 0.10 \\
\hline 3.Rationalize the covid-19 budget & 0.04 & 1.80 & 0.08 \\
\hline $\begin{array}{l}\text { 4.The socio-economic situation due to the } \\
\text { Covid-19 pandemic }\end{array}$ & 0.04 & 1.80 & 0.09 \\
\hline $\begin{array}{l}\text { 5.Negative information (hoax) from social } \\
\text { media about Covid-19 }\end{array}$ & 0.05 & 2.20 & 0.11 \\
\hline EFAS TOTAL SCORE & 1.00 & & 3,32 \\
\hline
\end{tabular}


The table above shows the results of the calculation of the value of external factors with the total value (opportunities and threats) of 3.32. The opportunity factor that has the highest score is 0.36 , there are three components, namely support from the village, the commitment of village officials and the community as well as community and organizational participation, while in the threat factor the highest value is the negative information component (Hoak) from social media about Covid-19 and other health. with a score of 0.11 . This means that there is still a lot of unofficial or irresponsible information circulating in the community, especially through social media.

\subsection{SIAGA VILLAGE IMPLEMENTATION STRATEGY}

The combination of the IFAS and EFAS matrices produces an external-internal matrix containing nine types of cells that show the total value combination according to the weights of the IFAS and EFAS matrices in a strong position in the range 3.00-4.00 which places the implementation of Siaga villages to prevent Covid-19 in Abuan Village, Bangli Regency is in the cell I in the internal and external matrices.

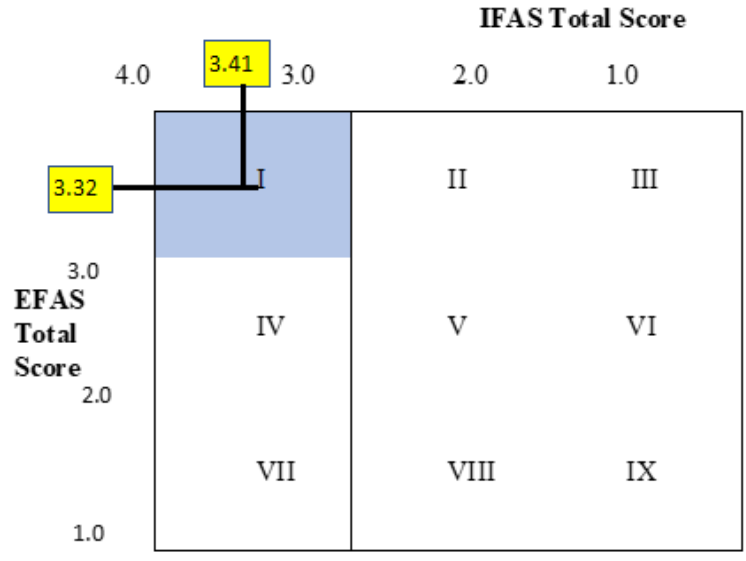

Figure 1 Position of the strategy on the IFAS and EFAS Matrix

Based on Figure 1, the strategy that suits these cells is to grow and develop with vertical integration, which can be done with a strategy that increases cooperation and coordination with the components involved in the growth of the Siaga village program in efforts to prevent COVID-19. The strategic obtained include:

1. Strategy 1, continue to carry out the development of Clean and Healthy Behavior Household by cadres/officers of the Puskesmas.

2. Strategy 2, carry out village forums regularly every month, discussing health, including Covid-19 in the village, involving figures/policyholders in the village and the community. 
3. Strategy 3, update the Village Head Forum Decree regularly issued by the Village Head every year.

4. Strategy 4, to disseminate information about Covid-19 through various media including social media

5. Strategy 5 , activating the role of health cadres during the Covid-19 pandemic in the form of prevention efforts in the form of socialization and handling so that people avoid negative information (hoax) from social media about Covid19 and other health.

Community Empowerment in Prevention of Covid-19 is all the efforts made by all components of society by exploring their potential so that they are empowered and able to play a role in preventing Covid-19 transmission, this is following the objectives of the Siaga Village program. Sulaeman, et al. (Sulaeman et al. (2012) ) stated that there are factors related to people's ability to identify health problems and people's ability to solve health problems. The health sector community empowerment model includes the ability to identify and solve health problems. Internal and external factors in a community at the level of community members, community institutions, community leadership, and access to health information have an important role in community empowerment in the health sector. The impact of the empowerment program in the health sector is changing people's behavior and increasing awareness in maintaining health as one of the capital in improving welfare (Pramudyani et al. (2019) ).

The factors that determine the implementation of the Siaga Village program in prevention efforts in Bangli Regency, Bali province consist of the dominant internal factors like strengths, namely the Clean and Healthy Lifestyle in each household by cadres/officers, and access to health service places that are reached by the community. Whereas a weakness in the village forum that discusses health (including Covid-19) which involves figures/policyholders in the village and the community that has not been routinely implemented every month. The external factor as the biggest threat is the existence of negative information (hoax) from social media about Covid-19 and other health aspects, while as an "opportunity" nothing is dominant. The implementation of Siaga Village programs requires collaboration from various parties, including village officials, community leaders, youth, NGOs, and all members of the community (Rochmawati (2010) ). The success of the Siaga Village Program requires the active role of various parties ranging from the central, provincial, district/city, sub-district to village and sub-district (Kesehatan and I (2015) ), and topdown and instructional approaches must be reduced (Kemenkes RI. 2012). Thus the success of its implementation requires the support of implementing officials to achieve the program goals (Suriyati et al. (2019) ).

Clean and healthy living habits are a set of behaviors that are practiced based on awareness as a result of learning that makes a person or family able to help themselves in the health sector and play an active role in realizing the health of their community (Bali (2012) ). A clean and healthy lifestyle is a reflection of a family lifestyle 
that always pays attention to and maintains the health of all family members. All health behaviors are carried out with awareness so that family members can help themselves in the health sector in the community. A clean and healthy lifestyle must be implemented as early as possible so that it becomes a positive habit in maintaining health (Proverawati and Rahmawati (2012) ).

\section{CONCLUSION}

Development strategy The implementation of the Siaga village program to prevent Covid-19 in Bangli Regency, Bali province is "to grow and develop with vertical integration", that is, with a strategy that increases cooperation and coordination of components related to the growth of the Siaga village program in efforts to prevent COVID. -19. A clean and healthy lifestyle is a must for every community household

\section{ACKNOWLEDGMENTS}

Our gratitude goes to the thesis research supervisors Magister in Regional Planning and Environmental Management, Postgraduate Program at University Mahasaraswati of Denpasar, reviewers, respondents, the Abuan Village Community, Bangli Regency, and the Village Head.

\section{REFERENCES}

Bali, D. K. P. (2012). Technical Guidelines for the PHBS Program (Clean and Healthy Lifestyle) Household Structure in Bali Province. Denpasar.

Kesehatan, K., \& I, R. (2010). General Guidelines for Active Siaga Village and Village Development. Health Promotion Center. Jakarta.

Kesehatan, K., \& I, R. (2014). Guidelines for Implementing Community-Based Health Efforts in Active Siaga Villages and Sub-Districts. Jakarta: Health Promotion Center.

Kesehatan, K., \& I, R. (2015). General Guidelines for Posyandu Management . Jakarta: Health Promotion Center.

Maharani, S. I., Martanti, L. E., \& Bahiyatun, B. (2018). Study of Community Empowerment through Siaga Village in the Context of Efforts to Reduce AKI in Bergas, Semarang Regency. Journal of Midwifery, 7(15), 10-16.

Misnaniarti, M. (2011). Study on the development of the Siaga Village in Ogan Ilir Regency. Journal of Health Service Management(02), 14-14.

Pramudyani, A., Setiawan, A., Fajariyansyah, A., \& Aji, G. L. (2019). Community Empowerment Efforts in the Health Sector Towards Siaga Villages. by KKN UAD in Watu Gajah and Mertelu, Gendangsari, Gunung Kidul.Journal of Empowerment: Publication of Community Service Results, 3(1).

Proverawati, A., \& Rahmawati, E. (2012). Clean and Healthy Living Behavior (PHBS). Yogyakarta: Nuha Medika., 2-105.

Rangkuti, F. (2016). Swot Analysis Techniques Dissecting Business Cases. PT Gramedia Pustaka Utama. Jakarta.

Rochmawati, A. (2010). The Relationship Between Health Cadre Activeness and the Devel- 
opment of the Siaga Village Program in Masaran District. Sragen Regency; Surakarta. Retrieved from https://eprints.uns.ac.id/id/eprint/4197

Sulaeman, E. S., Karsidi, R., Murti, B., Kartono, D. T., Waryana, W., \& Hartanto, R. (2012). Community empowerment model in the health sector, siaga village program study. Kesmas: National Public Health Journal, 7(4), 186-192.

Suriyati, N. P., Widnyana, I. K., \& Sukerta, I. M. (2019). Implementation Strategy of Labor and Prevention Planning Program in Tabanan District. International Journal of Contemporary Research and Review, 10(01), 21237-21244. Retrieved from https://dx.doi.org/ 10.15520/ijcrr.v10i01.648 10.15520/ijcrr.v10i01.648 